Article

\title{
Paradigm Shift or Paradigm Paralysis? National Mental Health and Capacity Law and Implementing the CRPD in Scotland
}

\author{
Jill Stavert \\ Centre for Mental Health and Capacity Law, School of Health and Social Care, Edinburgh Napier University, \\ Edinburgh EH11 4BN, UK; j.stavert@napier.ac.uk; Tel.: +44-(0)131-455-4553
}

Received: 4 April 2018; Accepted: 18 June 2018; Published: 29 June 2018

check for updates

\begin{abstract}
The United Nations Convention on the Rights of Persons with Disabilities (CRPD) highlights the need to actively remove obstacles to, and promote, the full and equal enjoyment of human rights by persons with disabilities. This is challenging us to revisit existing conceptions about what is genuine equal and non-discriminatory enjoyment of human rights by persons with cognitive, intellectual and psychosocial disabilities and to accept that a real and fundamental culture change is required in order to achieve this. Whilst many states are seeking to address CRPD requirements in law and policy, including those identified in its Article 12, it is arguable that these do not go far enough in order to secure this culture change. This article considers three issues that need to be resolved as part of the process of achieving this paradigm shift, namely capacity assessments as thresholds for involuntary interventions, authorising involuntary interventions and support for the exercise of legal capacity, both generally and in the particular context of Scotland's mental health and capacity laws. In doing so, it argues that it is debatable whether the CRPD paradigm shift can be realistically achieved by simply adapted or supplementing current legal and policy models.
\end{abstract}

Keywords: Convention on the Rights of Persons with Disabilities; equal recognition before the law; equal and non-discriminatory enjoyment of human rights; persons with cognitive, intellectual and psychosocial disabilities; involuntary interventions; CRPD paradigm shift realisation; National CRPD implementation; Scotland

\section{Introduction}

The overarching message of the United Nations Convention on the Rights of Persons with Disabilities (CRPD) is that persons with physical and mental disabilities are entitled to enjoy all human rights on an equal basis with others. What is becoming increasingly clear is that achievement of this requires more than persons with disabilities being provided with assistance, such as reasonable accommodation and support for the exercise of legal capacity (Articles 5(3) and 12(3) CRPD), where this is needed. It also requires a change in the traditional approach to equality and no-discrimination (UN Committee on the Rights of Persons with Disabilities (UN CRPD Committee) 2018a). The medical model of disability and pre-2006 international human rights instruments have viewed, and continue to view, impairment as a legitimate basis for the denial or restriction of human rights (Nilsson 2014; UN Human Rights Committee 2003, 2004; UN Committee on Economic, Social and Cultural Rights 2009). This does, however, allow for inequalities in human rights realisation which sits uncomfortably with the CRPD requirement that mental impairment must not be used as justification for the denial of rights enjoyment. CRPD compliance therefore necessitates a conceptual reframing of approaches to the realisation of the rights of persons with mental disabilities (Minkowitz 2017; Clough 2018).

Giving real effect to the rights identified in international human rights treaties requires a multi-dimensional approach, involving all sectors and civil society support and engagement at both 
national and international levels (Koh 1999; Simmons 2012). ${ }^{1}$ However, importantly, national policy and legislation are clear indicators of the level of state commitment to implementation, as is recognised by Articles 33(a)-(c) CRPD. Whilst several states, including Scotland, are attempting to address CRPD requirements in national law and policy it is not altogether clear whether its fundamental message about equal rights enjoyment is as yet being fully embraced. This is arguably notable in relation to the realisation of Article 12 (the right to equal recognition before the law). The following will therefore consider some of the conceptual issues that need to be overcome in law and policy for CRPD compliance to be achieved and contextualise this by reference to Scotland's mental health and capacity law.

\section{Background}

In adopting a largely social model of disability, that regards the state and societal practices and attitudes as the disabler rather than a person's disability, the CRPD highlights the need to actively remove obstacles to, and to promote, the full and equal enjoyment of human rights by persons with cognitive, intellectual and psychosocial disabilities. In the realisation of this it is important to recognise that not everyone starts from the same baseline and that some persons, including persons with mental disabilities, may require support to achieve equal enjoyment of their rights, the nature, degree and frequency of such support depending on an individual's particular circumstances. This is reflected in, amongst other things, the CRPD's requirement that in order to give effect to the universal right to exercise legal capacity on an equal basis (Articles 12(1) and 12(2) CRPD) states parties must 'provide access by persons with disabilities to the support they may require in exercising their legal capacity.' (Article 12(3) CRPD) and that measures relating to the exercise of legal capacity must ensure respect for the rights, will and preferences of the person (Article 12(4) CRPD).

The pursuit of equal enjoyment of human rights without discrimination does not mean that the human rights of persons with mental disabilities can never be denied or limited. It means that such denial or limitation must be based on the same criteria for all persons and must not be justified on the basis of a person's mental disability. In this connection, the CRPD Committee recognises that the inability to exercise one's legal capacity is an impediment to the equal enjoyment of all human rights (UN CRPD Committee 2014a) and one's ability to exercise legal capacity can be denied by involuntary interventions taking place both within institutions and in community settings (UN CRPD Committee 2014a, 2015, 2017a). Substitute decision-making arrangements that authorize such interventions on the basis of a diagnosis of mental disability or impairment and/or mental capacity assessments are therefore discriminatory (UN CRPD Committee 2014a, 2015, 2017a).

The committee has been unwavering in its calling for the abolition of substitute decision-making regimes $^{2}$ and their replacement entirely by 'supported decision-making' (see, for example, UN CRPD Committee 2017b, 2017c) and the position it has taken has been controversial (Martin et al. 2016). Nor has it been adopted by all other UN human rights bodies (see, for example, UN Human Rights Committee 2004; UN Committee against Torture 2013; UN Sub-Committee on Prevention of Torture

1 This is also recognised in the CRPD (Article 33).

2 Such as guardianship, conservatorship and involuntary psychiatric treatment. Owing to a lack of clarity over the definition of substitute decision-making in its General Comment No. 1 (para. 27) the CRPD Committee adopted a corrigendum, by way of clarification, in January 2018:

'Substitute decision-making regimes can take many different forms, including plenary guardianship, judicial interdiction and partial guardianship. However, these regimes have certain common characteristics: they can be defined as systems where: (a) legal capacity is removed from a person, even if this is in respect of a single decision; (b) a substitute decision maker can be appointed by someone other than the person concerned, and this can be done against his or her will; or (c) any decision made by a substitute decision maker is based on what is believed to be in the objective "best interests" of the person concerned, as opposed to being based on the person's own will and preferences.' 
2016; European Committee for the Prevention of Torture 2015³) or in European Convention of Human Rights (ECHR) jurisprudence. ${ }^{4}$ However, notwithstanding this, there have been various national attempts to engage and align law and policy more closely with the requirements of Article 12 CRPD if not fully with those of the CRPD Committee. Examples of this can be found in Australia, Canada and Northern Ireland. ${ }^{5}$ Proposed and suggested reform of Scotland's mental health and capacity law also has the CRPD firmly in mind (Scottish Government 2016a, 2016b, 2017, 2018b).

It should, however, not be forgotten that the impetus for the CRPD was that previously human rights of persons with disabilities had tended to be interpreted through the lens of medical models of disability (Arnardóttir and Quinn 2009; Bartlett 2013). Such models view human rights predominantly in terms of defining the perimeters of protection and intervention rather than as proactive enhancers of empowerment and autonomy (Gostin and Gable 2004; Kayess and French 2008; United Nations General Assembly 1971, 1991). They were accordingly regarded by persons with lived experience of disability as simply not delivering in terms of ensuring the equal and non-discriminatory enjoyment of such rights (Gostin and Gable 2004; Kayess and French 2008).

The CRPD not only reinforces the basic general human rights principle, identified in previous international human rights instruments, ${ }^{6}$ that human rights must be enjoyed equally and without distinction by all persons. It goes further than this. As already mentioned, traditional understandings of what constitutes the equal and non-discriminatory enjoyment of rights by persons with disabilities have tended to allow for differential treatment provided there is objective and reasonable justification for this (Nilsson 2014; UN Human Rights Committee 2003, 2004; UN Committee on Economic, Social and Cultural Rights 2009). ${ }^{7}$ However, the CRPD's bringing together and effectively integrating civil, political, social and economic rights and its principles of active inclusion, participation and autonomy arguably no longer allows for such differentiation (UN CRPD Committee 2018a; Goldsmidt 2017; Stavert and McGregor 2018). In short, the CRPD challenges us to engage with what this really means in the context of persons with mental disabilities and how such equality can genuinely be achieved so that its required paradigm shift becomes a reality (UN CRPD Committee 2018a). It requires us to seriously reconsider the entire legal, policy and practice landscape within which persons with mental disabilities are able to enjoy their human rights (Minkowitz 2017; Clough 2018). It is asking us to refocus on what these rights are actually supposed to be achieving for persons with mental disabilities. This is very much in line with Amartya Sen's capabilities approach (Sen 2005) where human rights should be justified essentially in terms of achieving those things that make for a fulfilled life. In this context, protection from abuse and discrimination in care and treatment and the adequate provision of the support and services required to enable full and effective inclusion, participation, recovery and rehabilitation are paramount considerations (Venkatapuram 2011).

The question therefore has to be asked as to whether the very different approach to rights enjoyment espoused by the CRPD can be achieved through simply adapting or supplementing existing

3 The CRPD Committee's position is, however, supported by the UN Working Group on Arbitrary Detention and the Office of the UN High Commissioner for Human Rights (UN Working Group on Arbitrary Detention 2015; UN High Commissioner for Human Rights 2017).

4 Which whilst increasingly interpreting the right to liberty (Article 5) and respect for private and family life, or autonomy (Article 8) expansively nevertheless accepts that, subject to strict criteria and safeguards, the rights of persons who are deemed lack mental capacity may be limited. See, for example, HL v UK (2005) 40 EHRR 32; Shtukaturov v Russia (App no 44009/05) (2012) 54 EHRR 27, paras. 87-89; Sykora v Czech Republic (App no 23419/07) (2012) ECHR 1960, paras. 101-3; and $X v$ Finland (App no 34806/040) (2012) ECHR 1371, para. 220. This was again recently evidenced in A-MV v Finland (App no 53251/13) ECtHR, 23 March 2017.

5 For example, Powers of Attorney Act 2014 (Vic) ss 87-89; Mental Health Act 2014 (Vic) Part 3, ss 12-27; Medical Treatment and Planning Act 2016 (Vic) ss 31, 32; Representation Agreement Act 1996 (Canada BC); Assisted Decision-Making (Capacity) Act 2015 (Ireland); Mental Capacity (Northern Ireland) Act 2016).

6 See, for example, Article 2 the Universal Declaration of Human Rights 1948; Article 2(1) International Covenant on Civil and Political Rights 1966; Article 2(2) International Covenant on Economic, Social and Cultural Rights 1966; Article 14 European Convention on Human Rights 1950; Article 2 African Charter on Human and Peoples' Rights 1982.

7 See also, for example, Religionsgemeinschaftder Zeugen Jehovas v Austria (Application No. 40825/98) (2009) 48 EHRR 17; Glor v Switzerland (Application No. 13444/04), unreported, 30 April 2009 (ECHR (Grand Chamber)). 
legal and policy frameworks. Certainly, as far as Article 12 CRPD is concerned, if environments are to be created that are conducive to the equal enjoyment of rights by persons with mental disabilities, it is necessary to address the use of capacity assessments to justify non-consensual interventions, the authorisation of involuntary interventions themselves and support for the exercise of legal capacity. In the following sections some observations will be made on the challenges these currently present in the broad sense. Scotland's mental health and capacity law will then be considered in order to provide national context although the discussion may be equally relevant to other jurisdictions.

\section{Paradigm Shifting: Achieving Equal and Non-Discriminatory Rights Enjoyment for Persons with Mental Disabilities}

\subsection{Mental Capacity Assessments as the Threshold to Interventions}

To date, there appears to be little appetite to completely remove the various forms of 'capacity' assessment that have been adopted across most, if not all, jurisdictions as a criterion for involuntary interventions in the case of persons with mental disabilities (McKay and Stavert 2017). For states parties to the ECHR such thresholds sit comfortably with this treaty's requirements, particularly in relation to Articles 5 (the right to liberty) and 8 (respect for private and family life), that links protective measures and non-consensual interventions with mental incapacity. This also mirrors the principles in Re T (Adult Re T (Adult: Refusal of Medical Treatment) $n t)^{8}$ and Re C (Adult: Refusal of Treatment $)^{9}$ that the refusal of treatment by persons with capacity must be respected. Indeed, the use of mental capacity thresholds has been promoted as the means by which equality can be established in terms of respect for refusals of treatment for physical and mental health conditions (Dawson and Szmukler 2006; Szmukler et al. 2010; Harper et al. 2016). Yet the CRPD Committee is highly uncomfortable about the use of capacity assessments predicated wholly or partly on the basis of a diagnosis of mental disability or impairment as these invariably open the door to substitute decision-making based on what others consider to be wise or unwise decisions and in the 'best interests' of the individual concerned (UN CRPD Committee 2014a). Such arrangements, the Committee argues, deny legal agency and allow little or no scope for giving effect to an individual's rights, will and preferences (UN CRPD Committee 2014a).

It has been argued that appropriately crafted substitute decision-making regimes that include a form of 'capacity threshold' (albeit not linked to diagnosis) can still give effect to an individual's rights, will and preferences (Essex Autonomy Project 2014; Martin et al. 2016). That being said, it is increasingly becoming clear that current mental capacity assessments themselves may leave a great deal to be desired. They may be unreliable in terms of lacking uniformity, depth and perceptions about the impact of mental disability and associated risk (House of Lords 2014; Mental Welfare Commission for Scotland 2016a; McKay and Stavert 2017). Not only does this run contrary to the notion of personhood which allows for the diversity in, and relational aspects of, decision-making which is common to all individuals (Kampf 2010; Quinn 2010; Gooding 2013; Flynn and Arstein-Kerslake 2014a) it provides a potentially discriminatory means of justifying interventions into the lives of persons with mental disabilities.

Indeed, if misperceptions about risk and the need to protect a person with mental disability from their own or others' actions dominate all mental capacity assessments then this is of considerable concern. To target and restrict an individual at risk rather than the perpetrator or other cause of the risk or harm is clearly discrimination (McKay and Stavert 2017). Conversely, where the risk or harm emanates from the individual themselves then an over-focus on risk may prevent questions being asked about whether the same decision to restrict a person's autonomy would be made for a person without the diagnosis of a mental disability. In order to realise rights on an equal basis there needs to

8 Re T (Adult: Refusal of Medical Treatment) [1992] EWCA Civ 18.

$9 \operatorname{Re}$ C (Adult: Refusal of Treatment) [1994] 1 All ER 819. 
proper consideration of what it is to allow for risk taking on an equal basis with others, the sufficiency of support for decision-making and, on the basis that equal risk taking means equal consequences, how to create environments where this can be achieved whilst at the same time taking into account and addressing an individual's particular needs. It is also important to avoid the temptation, however well-intended, to misinterpret the right to freedom from exploitation, violence and abuse identified in Article 16 CRPD as limiting an individual's Article 12 CRPD right (Keeling 2017).

\subsection{Effective Support for the Exercise of Legal Capacity Mechanisms and Their Implementation}

Despite increasing enthusiasm across the globe for 'supported decision-making' it would also appear that implementation of the Article 12 CRPD support paradigm still has a long way to go. Moreover, support for the exercise of legal capacity mechanisms remain almost overwhelmingly confined within existing structures which the CRPD Committee would regard as substitute decision-making (UN CRPD Committee 2018b). ${ }^{10}$ Several law reform models have been suggested (Victoria Law Reform Commission 2012; Australian Law Reform Commission 2014; Martin et al. 2016; Law Commission of Ontario 2017) and some legislative and non-legislative arrangements or changes arguably come close to Article 12 CRPD compliance. ${ }^{11}$ However, there is no evidence yet that any jurisdiction has fully achieved such compliance (Kohn and Blumenthal 2014; Carney 2014, 2015, 2017; Davidson et al. 2015; Stavert and McGregor 2018). Indeed, even where the Committee acknowledged that Sweden had abolished declarations of incapacity it also noted its concern that the appointment of administrators is a form of substitute decision-making and recommended that Sweden take immediate steps to replace this with supported decision-making (UN CRPD Committee 2014b).

It has to be acknowledged that, quite apart from abolishing laws and practices that permit substitute decision-making, the task of introducing widespread supported decision-making regimes that fulfil Article 12 CRPD requirements should not be under-estimated. Whilst pockets of research into the effectiveness of different types of support are currently being undertaken there is still a dearth of evidence-based arrangements to draw from (Carney 2014, 2017). The level of accompanying resourcing and policy, legal and practice culture shift that is required to effect such a change should also not be downplayed. The CRPD Committee has stressed the immediacy of such change on the basis that equal recognition before the law identified in Article 12 CRPD is a civil right and civil rights must take effect upon treaty ratification (UN CRPD Committee 2014a). However, a more realistic and workable solution may well be, as Terry Carney suggests, to assert that access to supported decision-making (given its intended wide-reaching effect in terms of rights enjoyment) is a socio-economic right which, given that implementation of socio-economic rights is inevitably resource intensive, therefore instead allows for progressive realisation (Carney 2017).

\subsection{Authorising Involuntary Interventions}

The CRPD Committee has not stated that all non-consensual interventions relating to persons with mental disabilities are prohibited. What it, and the CRPD, are stating is that if we are to genuinely support the equal and non-discriminatory enjoyment of human rights by persons with mental disabilities then such interventions must only be applied where they are justified by the same criteria for all persons (UN CRPD Committee 2014a, 2014b, 2017a). This is possible but perhaps difficult to conceptualise if one remains wedded to the notion that discrimination is still permissible if it can be objectively and reasonably justified.

It should be noted that the Committee has not stated that it is impossible for others to make decisions for a person with mental disabilities. It does acknowledge that there may be situations where after making 'significant efforts' it has not been practicable to determine an individual's will

10 See Footnote 2 above for the CRPD Committee's definition of substitute decision-making.

11 For examples please see Footnote 5 above. 
and preferences and that in such situation a "best interpretation of will and preferences" (as opposed to a best interests decision) may be adopted (UN CRPD Committee 2014a). Whilst there might be disagreement over whether this is interpreted as 'total support' or, in fact, a form of enlightened substitute decision-making (Series 2015; Quinn 2010; Booth-Glen 2012; Martin et al. 2016) it clearly recognises that there are limits to actively supporting a person to exercise their legal capacity (Gooding 2015). However, it is clear that adopting the 'best interpretation' approach is a last resort and only after strenuous efforts are made to give effect to the individual's will and preferences through supporting them to personally exercise their legal capacity. Moreover, the point at which 'best interpretations' are made must be uniformly applied to all persons. Similarly, it would also appear that non-discriminatorily applied emergency interventions are permissible where there is risk of imminent and grave harm although this is unlikely, in the view of Eiliónoír Flynn and Anna Arstein-Kerslake, to include forced medication or force-feeding (Flynn and Arstein-Kerslake 2017).

With these general, but important, challenges faced by all states borne in mind, this paper will now consider how the CRPD paradigm shift is and might be addressed in the context of law reform in Scotland. In this respect it is pertinent to look at the law at it currently stands, its weaknesses and gaps, as well as leverage point for its potential reform.

\section{Addressing the Paradigm Shift in Scotland}

It is true to say that Scotland's current mental capacity and mental health legislation was created with human rights, namely the ECHR, firmly in mind. The enactment of the Adults with Incapacity (Scotland) Act 2000 (the 2000 Act) and Mental Health (Care and Treatment) (Scotland) Act 2003 (the 2003 Act) followed many years of policy development (Scottish Law Commission 1995; Scottish Executive 2001) and consistent pressure from, and consultation with, professional, voluntary and user groups. This resulted in legislation that at the time became internationally regarded as leading examples of good practice in terms of being based on ECHR rights and person-centred principles that must be applied in the context of decisions regarding interventions and non-consensual care and treatment (Fischer 2006). This was followed by the Adult Support and Protection (Scotland) Act 2007 (the 2007 Act). This Act relates to 'adults at risk' (which may or may not include adults assessed as lacking capacity) and took forward many of the recommendations by the Scottish Law Commission in its report on Vulnerable Adults (Scottish Law Commission 1997) as well as being underpinned by almost identical principles to those in the 2000 and 2003 Acts. However, as the Act does not authorise involuntary interventions it is beyond the scope of this particular article.

\subsection{Capacity Thresholds and Support for the Exercise of Legal Capacity}

In-keeping with other jurisdictions, the eligibility threshold for consideration of interventions under the 2000 Act and civil compulsion under the 2003 Act are determined by capacity assessments. Implicit in both Acts is a rebuttable presumption of capacity, that capacity assessments must be decision-specific and the key objective of the underpinning principles is to ensure that the individual's autonomy is preserved insofar as it is possible both when interventions and non-consensual care and treatment are being considered and during their implementation (Scottish Parliament 1999; Scottish Parliament 2002).

Before interventions and non-consensual care and treatment may be considered under the 2000 Act it requires that an adult must be assessed as 'incapable' 'because of mental disorder to of inability to communicate because of physical disability. ${ }^{12}$ The 2003 Act, on the other hand, has the slightly different capacity test of 'significantly impaired decision-making ability' because of their mental disorder. ${ }^{13}$

12 Section 1(6) 2000 Act. Any inability to communicate which can be rectified through human or mechanical assistance is excluded here (Section 1(6) $2000 \mathrm{Act})$.

13 Sections 36(4)(b), 44(4)(b) and 64(5)(d) 2003 Act. 
'Significantly impaired decision-making ability' is not defined in the 2003 Act. However, the Act's Code of Practice makes it clear that whilst it is a concept that is separate to that of 'incapacity' as defined in the 2000 Act similar factors will in fact be considered to those taken into account in its assessment (Scottish Government 2005). This makes it a potentially broader concept than the more decision-specific capacity test under the 2000 Act and allows for someone to be both subject to compulsion under the 2003 Act whilst at the same time retaining the ability to consent to specific treatments.

The different approach to capacity assessment in the 2003 Act is the result of a recommendation by the Scottish Government appointed Millan Committee's in its review of the former Mental Health (Scotland) Act 1984. The Milan Committee had considered what constitutes an ethical justification for non-consensual treatment. In doing so it noted that impaired judgement and mental disorder are not necessarily linked, that a person may have fluctuating and ambivalent mental states and that disagreeing with professionals' opinions is not necessarily impaired judgement. It also noted, however, that compulsion should be justified on the basis of an assessment of impairment together also with the nature and degree of risk, and the likely benefits of treatment (Scottish Executive 2001).

\subsection{Accommodating and Supporting an Individual's Rights, Will and Preferences}

In terms of respecting the views and autonomy of individuals in the face of and during involuntary interventions the main ingredients can be found in the 2000 and 2003 Acts. ${ }^{14}$ Specific legislative principles in both Acts require that the ascertainable present and past wishes of the individual are taken into account and for interventions to be the least restrictive in the circumstances and only to take place as a last resort where the benefit of such intervention cannot otherwise be achieved. ${ }^{15}$ The 2003 Act's principles also require that a patient must not be treated in a way that is less favourable than the way in which someone who is not a patient is treated, thus emphasising the need for non-discrimination. ${ }^{16}$

Although limited in scope, support for the exercise of legal capacity can be discerned in both the Acts. There is a requirement in the 2003 Act to encourage and support a patient's participation in care and treatment decisions made concerning them. ${ }^{17}$ Those responsible for the implementation of 2000 Act interventions must encourage the development of an adult's skills to deal with their own welfare, property and financial affairs. ${ }^{18}$ The 2003 Act established a right to receive, with corresponding duty on local authorities and health boards to provide, independent advocacy for all persons with mental disorder. ${ }^{19}$ This duty has recently been expanded to include reporting on independent advocacy provision and planning to the Mental Welfare Commission for Scotland. ${ }^{20}$ Comparable provision is not found in the 2000 Act although sheriffs are obliged to take account of an adult's wishes and feelings as conveyed by an independent advocate. ${ }^{21}$ The 2003 Act also requires that clinicians and the Mental Health Tribunal for Scotland have regard for a patient's wishes expressed in a psychiatric advance statement and to record reasons for overriding such wishes. ${ }^{22}$ This has been recently reinforced by the imposition of duties on health boards, overseen by the Mental Welfare Commission, to record the existence (and withdrawal) of advance statements and publicise any support they offer to patients to make or withdraw such statements. ${ }^{23}$

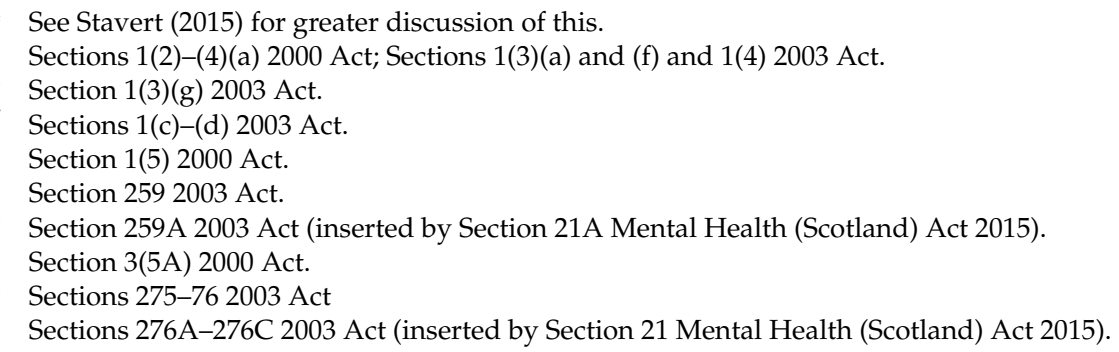


However, the ability to give real effect to the legal capacity of those with mental disabilities is somewhat constrained by the fact that the legislative principles in both Acts are non-hierarchical and firmly contained within substitute decision-making structures. Support for expressing and a giving effect to the individual's wishes and feelings is also largely confined to assistance with communication and mentioned in the Acts' codes of practice (Scottish Government 2005, 2011, 2018b). Moreover, it is unclear who is ultimately responsible for ensuring that access to the identified support is provided and, whilst it is arguably implied that it should be provided, there is no statutory requirement that this occurs before interventions are being considered (Stavert 2015; Martin et al. 2016; McKay and Stavert 2017). This therefore allows the potential for other factors to override the individuals' wishes and feelings.

\subsection{Embracing the CRPD Paradigm Shift in Scotland}

The combined effect of the Scotland Act 1998 and Human Rights Act 1998 is that all legislation, policy and public body actions in Scotland must be ECHR compliant and ECHR rights can be enforced through national courts. ${ }^{24}$ Indeed, non- ECHR compliant devolved Scottish legislative provisions and actions of the Scottish Ministers will be deemed invalid. This embedding only occurs in the case of the ECHR and no other human rights treaties and the ECHR therefore currently takes precedence over such treaties under national law. However, as previously stated, the jurisprudence concerning Articles 5 and 8 and persons with mental disabilities continues to link justification for involuntary interventions with mental disorder diagnosis and/or mental capacity assessments as was strongly reinforced by the $2017 A M V v$ Finland ${ }^{25}$ ruling.

CRPD rights do not have the same legal purchase as ECHR rights given that they are not incorporated in Scottish law. Whilst this might therefore be viewed as an impediment to embracing the CRPD model this treaty is nevertheless influential. ${ }^{26}$ Evidence of this influence can be seen in a number of different ways in relation to both the CRPD generally and Article 12 CRPD more particularly.

At the more general level, in 2016 the Scottish Government pledged to give effect to CRPD rights in its A Fairer Scotland for Disabled People-Our Delivery Plan to 2021 for the United Nations Convention on the Rights of Persons with Disabilities (Scottish Government 2016a). In the same year the Mental Welfare Commission for Scotland and Scottish Human Rights Commission called for the next mental health strategy to be explicitly based around a human rights approach (Scottish Human Rights Commission and Mental Welfare Commission for Scotland 2016) and this was reflected in the Scottish Government's Mental Health Strategy 2017-2027 (Scottish Government 2017) ${ }^{27}$ although

24 Sections 29(2)(d) and 57(2) Scotland Act 1998; Sections 2, 3 and 6 Human Rights Act 1998.

25 Footnote 3 above.

26 Noting the UK's obligations (as a state party to the CRPD and its Optional Protocol) under international law to give effect nationally to its requirements, the European Court of Human Rights is required to take the CRPD as a higher source of international law into account when interpreting ECHR rights and the fact that proposed devolved Scottish legislation and actions of the Scottish Ministers can be prevented by the UK Government for non-compliance with the UK's international obligations, which includes those under the CRPD (Sections 35(1)(a) and 58(1) Scotland Act 1998.

27 See:

"Scotland's commitment to meeting the needs of those who require access to mental health services reflects the importance we attach to realising the right of every individual to the highest attainable standard of physical and mental health."

(p. 12)

and:

"Adults with Incapacity legislation should fully reflect the requirements of the United Nations Convention on the Rights of Persons with Disabilities (UNCRPD), with particular emphasis on provision of supported decision making, addressing issues around deprivation of liberty and the interaction of AWI legislation with the legislation on mental health and adult support and protection."

(p. 34) 
greater clarity is awaited on exactly how its proposed outcomes will be achieved. Implementation of the social and economic rights identified in the CRPD will also arguably be bolstered by the fact that the UK Equality Act 2010 public sector duty regarding socio-economic inequalities ${ }^{28}$ came into force in Scotland in April 2018. ${ }^{29}$ In regard to Article 12, the Scottish Government is actively considering how these can be given effect to achieve greater CRPD compliance in its current consideration of reform of the 2000 Act (Scottish Government 2018a).

Meanwhile, at an operational level, certain sheriffdoms are also seeking to give practical effect to Article 12. The Sheriffdom of Lothian and the Borders has, for example, directed that all 2000 Act applications must contain details of the present and past wishes and feelings of the adult so far as they can be ascertained or, where it is not possible to ascertain these, then a statement as to why this is not possible and any steps that have been taken (including any assistance and/or support provided) to ascertain them (Sheriffdom of Lothian and the Borders 2016).

There remains widespread support for the principles that underpin the 2000 and 2003 Acts (McKay and Stavert 2017). However, questions have arisen about the extent to which the principles regarding respect for individual's wishes and feelings, benefit and least restrictive options are truly reflected in decisions concerning non-consensual care and treatment and other interventions (McKay and Stavert 2017). It has been suggested that whilst the Acts have been promoted as enhancing and protecting the rights of people with cognitive, intellectual and psychosocial disabilities the reality is that they merely more clearly articulate the power of the state to undertake or authorise involuntary interventions (People First (Scotland) 2011; Mental Welfare Commission for Scotland 2014, 2015a, 2015b, 2016a). Research has also indicated a lack of awareness and application of the principles of the legislation in practice amongst health care staff (Scottish Human Rights Commission 2012; Mental Welfare Commission for Scotland 2016b). Such concerns do seem to be supported by the fact that there has been a significant and longstanding trend of increased use of both mental health and incapacity legislation in Scotland. Guardianships rose across Scotland between 2015/16 and 2016/17 by 12.5\% (Mental Welfare Commission for Scotland 2017). Levels of mental health legislation compulsion across Scotland are currently the highest they have been in at least 15 years (Mental Welfare Commission for Scotland 2018a). The reasons for these increases are not entirely clear. Greater awareness of the legislation, the impact of the European Court of Human Rights Bournewood and UK Supreme Court Cheshire West rulings ${ }^{30}$ (extending the reach of Article 5 ECHR, and therefore the need for legal safeguards, for persons assessed as lacking capacity to consent to deprivations of liberty in a wide range of health and social care settings), demographic changes and service redesign may well be contributing factors (McKay and Stavert 2017). ${ }^{31}$ At the same time there has been a steady increase in the number of persons accessing advocacy but a continued overall trend in reducing resourcing (statutory and otherwise) for advocacy with consequent gaps in provision in relation to, amongst others, children and young persons, dementia, learning disabilities, autism, mentally ill persons in prison and collective advocacy and prioritisation of referrals (often in favour of those facing compulsory measures) (Scottish Independent Advocacy Alliance 2016;

28 Section 1 Equality Act 2010.

29 The Equality Act 2010 (Authorities subject to the Socio-economic Inequality Duty) (Scotland) Regulations 2018 SSI 2018/101.

30 HL v UK (2005) 40 EHRR 32 ('Bournewood'); P (by his litigation friend the Official Solicitor) (Appellant) $v$ Cheshire West and Chester Council and another (Respondents); $P$ and $Q$ (by their litigation friend, the Official Solicitor)(Appellants) v Surrey County Council (Respondent) [2014] UKSC 1 ('Cheshire West').

31 It should also perhaps be noted that such increases are not confined to Scotland. A similar situation exists, for example, in England and Wales where formal detentions under mental health legislation have been reported to have increased by 10 per cent in between 2013/14 and 2014/15 and by 9 per cent between 2014/2015 and 2015/2016, the 2015/2016 rate being the highest since 2005/2006 (NHS Digital 2016). For 2016/2017 there was an estimate increase of 2 per net since the previous year (NHS Digital 2017). Applications to the Court of Protection in England and Wales regarding persons who lack capacity, and orders made by this court, also appear to be increasing although this seems to be largely attributable to deprivations of liberty rather than deputyship (the equivalent of guardianship) (UK Ministry of Justice 2017). 
Mental Welfare Commission for Scotland 2018b; Stavert 2018). Moreover, the numbers given for those accessing advocacy does not necessarily reflect all persons who actually require advocacy.

If we are to accept that it now appears that some aspects of such Scottish law are indeed discriminatory and permit the differential and unequal enjoyment of human rights by persons with mental disabilities this is undoubtedly of concern.

\section{Conclusions: Reforming and Reconceptualising, But Not Reinventing}

In 2017, following a law reform scoping exercise, the Mental Welfare Commission for Scotland and Centre for Mental Health and Capacity Law (Edinburgh Napier University) concluded that to ensure compliance with developing international human rights standards in the CRPD and ECHR Scotland's mental health and capacity law needs to be revisited and, where necessary, reframed (McKay and Stavert 2017). Its recommendations included that:

'There should be a long-term programme of law reform, covering all forms of non-consensual decision-making affecting people with mental disorders. This should work towards a coherent and non-discriminatory legislative framework which reflects UNCRPD and ECHR requirements and gives effect to the rights, will and preferences of the individual.' (McKay and Stavert 2017)

It has been suggested that better Article 12 CRPD compliance might be achieved by, amongst other things, amending the 2000 and 2003 Acts to expressly reflect the presumption in favour of capacity and giving effect to the adult's wishes and feelings and being clearer about when supported decision-making is provided and who provides it (Martin et al. 2016; McKay and Stavert 2017). But is this enough?

As previously stated, the CRPD paradigm shift requires a significant transformation in approaches to rights enjoyment by persons with cognitive, intellectual and psychosocial disabilities (Quinn 2010; UN CRPD Committee 2014a, 2017a, 2018a; Clough 2018). Whilst this applies to the enjoyment of rights in all situations it is particularly brought into sharp relief in the context of non-consensual care, treatment and proxy decision-making.

The CRPD paradigm shift achievement is one of equality and non-discrimination in the enjoyment of all human rights by persons with mental disabilities. Law and policy is integral to national implementation of this standard. However, to give it real effect nationally will require, importantly, a fundamental reconceptualising of existing notions about autonomy, risk and the objective of support for the exercise of legal capacity as reflected in law and policy. It also requires real engagement by those stakeholders in all sectors who are responsible for implementing transformative law and policy. In the absence of this it is doubtful that the necessary culture shift can be achieved through simply adapting and supplementing law, policy and practices within existing structures.

Funding: This research received no external funding.

Conflicts of Interest: The author declares no conflicts of interest.

\section{References}

Arnardóttir, Oddný Mjöll, and Gerard Quinn, eds. 2009. The UN Convention on the Rights of Persons with Disabilities: European and Scandinavian Perspectives. Leiden: BRILL.

Australian Law Reform Commission. 2014. Equality, Capacity and Disability in Commonwealth Laws: Final Report. Sydney: Australian Law Reform Commission.

Bartlett, Peter. 2013. Implementing a Paradigm Shift: Implementing the Convention on the Rights of Persons with Disabilities in the Context of Mental Disability Law. In Torture in Healthcare Settings: Reflections on the Special Rapporteur on Torture's 2013 Thematic Report. Washington: Centre for Human Rights and Humanitarian Law, American University Washington College of Law.

Booth-Glen, Kristin. 2012. Changing Paradigms: Mental Capacity, Legal Capacity, Guardianship, and Beyond. Columbia Human Rights Law Review 44: 93-169. 
Carney, Terry. 2014. Clarifying, Operationalising and Evaluating Supported Decision-Making Models. Research and Practice in Intellectual and Developmental Disabilities 1: 46-50. [CrossRef]

Carney, Terry. 2015. Supporting People with Cognitive Disability with Decision-making: Any Australian law reform contributions? Research and Practice in Intellectual and Developmental Disabilities 2: 6-16. [CrossRef]

Carney, Terry. 2017. Prioritising Supported Decision-Making: Running on Empty or a Basis for Glacial-To-Steady Progress? Laws 6: 18. [CrossRef]

Clough, Beverley A. 2018. New Legal Landscapes: (Re)Constructing the Boundaries of Mental Capacity Law. Medical Law Review 26: 246-75. [CrossRef] [PubMed]

Davidson, Gavin, Berni Kelly, Geraldine Macdonald, Maria Rizzo, Louise Lombard, Oluwaseye Abogunrin, Victoria Clift-Matthews, and Alison Martin. 2015. Supported Decision Making: A review of the international literature. International Journal of Law and Psychiatry 38: 61-67. [CrossRef] [PubMed]

Dawson, John, and George Szmukler. 2006. Fusion of mental health and incapacity legislation. British Journal of Psychiatry 188: 504-9. [CrossRef] [PubMed]

Essex Autonomy Project. 2014. Achieving CRPD Compliance. Report. September 22. Available online: http:/ / autonomy.essex.ac.uk/uncrpd-report (accessed on 16 March 2018).

European Committee for the Prevention of Torture. 2015. CPT Standards. CPT/Inf/E 2002, 1-Rev. Strasbourg: European Committee for the Prevention of Torture.

Fischer, Jennifer. 2006. A Comparative Look at the Right to Refuse Treatment for Involuntarily Hospitalised Persons with Mental Illness. Hastings International and Comparative Law Review 29: 153-75.

Flynn, Eiliónoír, and Anna Arstein-Kerslake. 2014a. Legislating Personhood: Realising the Right to Support in Exercising Legal Capacity. International Journal of Law in Context 10: 81-104. [CrossRef]

Flynn, Eiliónoír, and Anna Arstein-Kerslake. 2014b. The Support Model of Legal Capacity: Fact, Fiction, Fantasy? Berkeley Journal of International Law 32: 134-53.

Flynn, Eiliónoír, and Anna Arstein-Kerslake. 2017. State intervention in the lives of people with disabilities: The case for a disability-neutral framework. International Journal of Law in Context 13: 39-57. [CrossRef]

Goldsmidt, Jenny E. 2017. New Perspectives on Equality: Towards Transformative Justice through the Disability Convention? Nordic Journal of Human Rights 35: 1-14. [CrossRef]

Gooding, Piers. 2013. Supported Decision-Making: A Rights-Based Disability Concept and its Implications for Mental Health Law. Psychiatry, Psychology and Law 20: 431-51. [CrossRef]

Gooding, Piers. 2015. Navigating the 'Flashing Amber Lights' of the Right to Legal Capacity in the United Nations Convention on the Rights of Persons with Disabilities: Responding to Major Concerns. Human Rights Law Review 15: 45-71. [CrossRef]

Gostin, Lawrence O., and Lance Gable. 2004. The Human Rights of Persons with Mental Disabilities: A Global Perspective on the Application of Human Rights Principles to Mental Health. Maryland Law Review 63: 20-121. [CrossRef]

Harper, Colin, Colin Davidson, and Roy McClell. 2016. No Longer 'Anomalous, Confusing and Unjust': The Mental Capacity Act (Northern Ireland) 2016. International Journal of Mental Health and Capacity Law 22: 57-70. [CrossRef]

House of Lords Select Committee on the Mental Capacity Act. 2014. Report of Session 2013-14: Mental Capacity Act 2005: Post-Legislative Scrutiny (2014) HL 139. London: The Stationery Office Limited.

Kampf, Anna. 2010. Involuntary Treatment Decisions: Using Negotiated Silence to Facilitate Change? In Rethinking Rights-Based Mental Health Laws. Edited by Bernadette McSherry and Penelope Weller. Oxford: Hart Publishing.

Kayess, Rosemary, and Phillip French. 2008. Out of Darkness into Light? Introducing the Convention on the Rights of Persons with Disabilities. Human Rights Law Review 8: 1-34. [CrossRef]

Keeling, Amanda. 2017. Organising objects: Adult safeguarding practice and article 16 of the United Nations Convention on the Rights of Persons with Disabilities. International Journal of Law and Psychiatry 53: 77-87. [CrossRef] [PubMed]

Koh, Harold Hongju. 1999. How is International Human Rights Law Enforced? Indiana Law Journal 74: $1397-417$. Kohn, Nina A., and Jeremy A. Blumenthal. 2014. A Critical Assessment of Supported Decision-making for Persons Aging with Intellectual Disabilities. Disability and Health Journal 7: S40-S43. [CrossRef] [PubMed]

Law Commission of Ontario. 2017. Legal Capacity, Decision-Making and Guardianship: Final Report. Toronto: Law Commission of Ontario. 
Martin, Wayne, Sabine Michalowski, Jill Stavert, Adrian Ward, Alex Ruck Keene, Colin Caughey, Alison Hempsey, and Rebecca McGregor. 2016. The Essex Autonomy Project Three Jurisdictions Report: Towards Compliance with CRPD Art. 12 in Capacity/Incapacity Legislation across the UK. Colchester: University of Essex.

McKay, Colin, and Jill Stavert. 2017. Scotland's Mental Health and Capacity Law: The Case for Reform. Edinburgh: Mental Welfare Commission for Scotland, Edinburgh: Centre for Mental Health and Capacity Law, Edinburgh Napier University.

Mental Welfare Commission for Scotland. 2014. Visit and Monitoring Report: Updated Survey of Recorded Matters. October. Available online: http://www.mwcscot.org.uk/media/203366/updated_survey_of_ recorded_matters_2_.pdf (accessed on 25 March 2018).

Mental Welfare Commission for Scotland. 2015a. Visit and Monitoring Report: Suspension of Detention Visits (May-Dec 2014). July. Available online: http://www.mwcscot.org.uk/media/233726/suspension_of_ detention_report_final_1.pdf (accessed on 25 March 2018).

Mental Welfare Commission for Scotland. 2015b. Visit and Monitoring Report: Visits to People on Longer Term Community-Based Compulsory Treatment Orders. December. Available online: http:/ /www.mwcscot.org. uk/media/243429/ccto_visit_report.pdf (accessed on 25 March 2018).

Mental Welfare Commission for Scotland. 2016a. Consultation Report: Capacity, Detention, Supported Decision Making and Mental Ill Health. February. Available online: https:/ /www.mwcscot.org.uk/media/371015/ capacity_detention_supported_decision_making_and_mental_ill_health.pdf (accessed on 25 March 2018).

Mental Welfare Commission for Scotland. 2016b. Visit and Monitoring Report-Intensive Psychiatric Care in Scotland 2015. March. Available online: http://www.mwcscot.org.uk/media/315618/intensive_ psychiatric_case_in_scotland_report_final.pdf (accessed on 25 March 2018).

Mental Welfare Commission for Scotland. 2017. Adults with Incapacity Act Monitoring Report 2016-17. October. Available online: https://www.mwcscot.org.uk/media/389068/awi_monitoring_report_2016-17. pdf (accessed on 25 March 2018).

Mental Welfare Commission for Scotland. 2018a. Mental Health Act Monitoring Report 2016-17. October 2017, Reviewed February 2018. Available online: https://www.mwcscot.org.uk/media/395255/mha_ monitoring_report2016-17_feb2018.pdf (accessed on 25 March 2018).

Mental Welfare Commission for Scotland. 2018b. The Right to Advocacy-A Review of Advocacy Planning Across Scotland. March. Available online: https://www.mwcscot.org.uk/media/395529/the_right_to_ advocacy_march_2018.pdf (accessed on 19 March 2018).

Minkowitz, Tina. 2017. CRPD and transformative equality. International Journal of Law in Context 13: 77-86. [CrossRef]

NHS Digital. 2016. Inpatients Formally Detained in Hospitals under the Mental Health Act 1983, and Patients Subject to Supervised Community Treatment-Uses of the Mental Health Act: Annual Statistics, 2015/2016. November 30. Available online: http:/ / www.content.digital.nhs.uk/catalogue/PUB22571/inp-det-m-h-a1983-sup-com-eng-15-16-rep.pdf (accessed on 25 March 2018).

NHS Digital. 2017. Inpatients Formally Detained in Hospitals under the Mental Health Act 1983, and Patients Subject to Supervised Community Treatment-Uses of the Mental Health Act: Annual Statistics, 2016/2017. October 10. Available online: https:/ / digital.nhs.uk/catalogue/PUB30105 (accessed on 25 March 2018).

Nilsson, Anna. 2014. Objective and Reasonable? Scrutinising Compulsory Mental Health Interventions from Non-discrimination Perspective. Human Rights Law Review 14: 459-85. [CrossRef]

People First (Scotland). 2011. Citizens' Grand Jury Report: Care, Protection and Human Rights or Danger, Neglect and Human Wrongs? May. Available online: http://www.viascotland.org.uk/webfm_send/304/ citizensgrand-jury-report.pdf (accessed on 2 April 2018).

Quinn, Gerard. 2010. Concept Paper-Personhood and Legal Capacity_Perspectives on the Paradigm Shift of Article 12 CRPD. Paper presented at HOOD Conference, Harvard Law School, Cambridge, MA, USA, February 20.

Scottish Executive. 2001. New Directions: Review of the Mental Health (Scotland) Act 1984. SE/2001/56. January. Available online: http://www.mhtscotland.gov.uk/mhts/files/Millan_Report_New_Directions. pdf (accessed on 24 March 2017).

Scottish Government. 2005. Mental Health (Care and Treatment) (Scotland) Act 2003. Code of Practice. Volume 2. Available online: http:/ / www.gov.scot/Resource/Doc/57346/0017054.pdf (accessed on 28 March 2018). 
Scottish Government. 2011. Code of Practice for Persons Authorised under Intervention Orders and Guardians under the Adults with Incapacity (Scotland) Act 2000. Available online: http:/ / www.gov.scot/Resource/ Doc/347717/0115820.pdf (accessed on 2 April 2018).

Scottish Government. 2016a. A Fairer Scotland for Disabled People-Our Delivery Plan to 2021 for the United Nations Convention on the Rights of Persons with Disabilities. Edinburgh. Available online: http:/ /www. gov.scot/Resource/0051/00510948.pdf (accessed on 20 March 2018).

Scottish Government. 2016b. Responses to the Scottish Government's Consultation on the Scottish Law Commission's Review of Adults with Incapacity. June. Available online: http:/ / www.gov.scot/Resource/ 0050/00502699.pdf (accessed on 20 March 2018).

Scottish Government. 2017. Mental Health Strategy: 2017-2027. March 30. Available online: http:/ /www.gov. scot/Resource/0051/00516047.pdf (accessed on 20 March 2018).

Scottish Government. 2018a. Consultation Paper: Adults with Incapacity (Scotland) Act 2000 Proposals for Reform. Edinburgh. January. Available online: http://www.gov.scot/Publications/2018/01/4350/downloads\# res530800 (accessed on 20 March 2018).

Scottish Government. 2018b. Adults with Incapacity (Scotland) Act 2000: Code of Practice for Continuing and Welfare Attorneys. February. Available online: http://www.gov.scot/Resource/0053/00532315.pdf (accessed on 2 April 2018).

Scottish Human Rights Commission. 2012. Getting It Right?: Human Rights in Scotland. October. Available online: http:/ / www.snaprights.info/wp-content/uploads/2016/01/Getting-it-Right-An-Overview-ofHuman-Rights-in-Scotland.pdf (accessed on 20 February 2018).

Scottish Human Rights Commission and Mental Welfare Commission for Scotland. 2016. Human Rights in Mental Health Care in Scotland: A Report on Progress towards Meeting Commitment 5 of the Mental Health Strategy Mental Health Strategy for Scotland: 2012-2015. September. Available online: http: / / www.mwcscot.org.uk/media/240757/human_rights_in_mental_health_care_in_scotland.pdf (accessed on 20 February 2018).

Scottish Independent Advocacy Alliance. 2016. Map of Advocacy across Scotland 2015-2016 Edition. Available online: https://www.siaa.org.uk/wp-content/uploads/2017/09/SIAA_Advocacy_Map_2015-16-1.pdf (accessed on 20 February 2018).

Scottish Law Commission. 1995. Report on Incapable Adults. Scot Law Com No 151. September. Available online: https:/ / www.scotlawcom.gov.uk/files/5013/2758/0994/rep151_1.pdf (accessed on 30 March 2018).

Scottish Law Commission. 1997. Report on Vulnerable Adults. Scot Law Com No 158. Available online: https: / www.scotlawcom.gov.uk/ files/8412/7989/7469/rep158.pdf (accessed on 30 March 2018).

Scottish Parliament. 1999. Adults with Incapacity (Scotland) Bill Policy Memorandum. SP Bill 5-PM. Session 1. Edinburgh: The Stationery Office. Available online: http://www.parliament.scot/S1_Bills/Adults\% 20with\%20Incapacity\%20(Scotland)\%20Bill/b5s1pm.pdf (accessed on 14 March 2018).

Scottish Parliament. 2002. Mental Health (Scotland) Bill Policy Memorandum. SP Bill 64-PM. Session 1. Edinburgh: The Stationary Office. Available online: http:/ / www.parliament.scot/S1_Bills/Mental\%20Health\%20(Care\% 20and\%20Treatment)\%20(Scotland)\%20Bill/b64s1pm.pdf (accessed on 14 March 2018).

Sen, Amartya. 2005. Human Rights and Capabilities. Journal of Human Development 6: 151-66. [CrossRef]

Series, Lucy. 2015. Relationships, autonomy and legal capacity: Mental capacity and support paradigms. International Journal of Law and Psychiatry 40: 80-91. [CrossRef] [PubMed]

Sheriffdom of Lothian and the Borders. 2016. Practice Note No 1 of 2016, Applications under the Adults with Incapacity (Scotland) Act 2000. March. Available online: www.scotcourts.gov.uk/rules-and-practice/ practice-notes/sheriff-court-practice-notes-(civil) (accessed on 2 March 2018).

Simmons, Beth A. 2012. Reflections on Mobilizing for Human Rights. Journal of International Law and Politics 44: 729-50.

Stavert, Jill. 2015. The Exercise of Legal Capacity, Supported Decision-Making and Scotland's Mental Health and Incapacity Legislation: Working with CRPD Challenges. Laws 4: 296-313. [CrossRef]

Stavert, Jill. 2018. Mental Welfare Commission for Scotland Report: The Right to Advocacy-A Review of Advocacy Planning across Scotland. Mental Capacity Report: Scotland. Issue 84. Edinburgh: Mental Welfare Commission for Scotland, April.

Stavert, Jill, and Rebecca McGregor. 2018. Domestic legislation and international human rights standards: The case of mental health and incapacity. International Journal of Human Rights 22: 70-89. [CrossRef] 
Szmukler, George, Rowena Daw, and John Dawson. 2010. A model law fusing incapacity and mental health legislation. Journal of Mental Health Law 20: 9-22. [CrossRef]

UK Ministry of Justice. 2017. Family Court Statistics Quarterly: July to September 2017. December 14. Available online: https://www.gov.uk/government/uploads/system/uploads/attachment_data/file/ 666627 / family-court-stats-july-september-2017.pdf (accessed on 25 March 2018).

UN Committee against Torture. 2013. Concluding Observations on the Combined Fifth and Sixth Periodic Reports of The Netherlands, Adopted by the Committee at its Fiftieth Session (6-31 May 2013). CAT/C/NLD/CO/5-6. Geneva: Committee against Torture, June 20.

UN Committee on Economic, Social and Cultural Rights. 2009. General Comment 20: Non-Discrimination in Economic, Social and Cultural Rights (Art. 2(2)). E/C.12/GC/20, 2 July 2009; 16 IHRR 925 (2009). Geneva: UN Committee on Economic, Social and Cultural Rights (CESCR), para. 13.

UN Committee on the Rights of Persons with Disabilities (UN CRPD Committee). 2014a. General Comment No. 1 (2014) Article 12: Equal Recognition before the Law. CRPD/C/GC/1. Geneva: UN Committee on the Rights of Persons with Disabilities, May 11.

UN Committee on the Rights of Persons with Disabilities (UN CRPD Committee). 2014b. Concluding Observations on the Initial Report of Sweden. CRPD/C/SWE/CO/1. Geneva: UN Committee on the Rights of Persons with Disabilities, May 12.

UN Committee on the Rights of Persons with Disabilities (UN CRPD Committee). 2015. Guidelines on Article 14 of the Convention on the Rights of Persons with Disabilities: The Right to Liberty and Security of Persons with Disabilities. Geneva: UN Committee on the Rights of Persons with Disabilities, September.

UN Committee on the Rights of Persons with Disabilities (UN CRPD Committee). 2017a. General Comment No. 5 (2017) on Living Independently and Being Included in the Community. CRPD/C/GC/5. Geneva: UN Committee on the Rights of Persons with Disabilities, October 27.

UN Committee on the Rights of Persons with Disabilities (UN CRPD Committee). 2017b. Concluding Observations on the Initial Report of the United Kingdom of Great Britain and Northern Ireland. CRPD/C/GBR/CO/1. Geneva: UN Committee on the Rights of Persons with Disabilities, October 3.

UN Committee on the Rights of Persons with Disabilities (UN CRPD Committee). 2017c. Concluding Observations on the Initial Report of Latvia. CRPD/C/LVA/CO/1. Geneva: UN Committee on the Rights of Persons with Disabilities, October 10.

UN Committee on the Rights of Persons with Disabilities (UN CRPD Committee). 2018a. General Comment No. 6 (2018) on Equality and Non-Discrimination. CRPD/C/GC/6. Geneva: UN Committee on the Rights of Persons with Disabilities, March 9.

UN Committee on the Rights of Persons with Disabilities (UN CRPD Committee). 2018b. General Comment No. 1 (2014) Article 12: Equal Recognition before the Law-Corrigendum. CRPC/C/GC/1/Corr.1. Geneva: UN Committee on the Rights of Persons with Disabilities, para. 27, January 26.

UN High Commissioner for Human Rights. 2017. Human Rights Council 34th Session, 27 February-24 March 2017-Mental Health and Human Rights. A/HRC/34/32. Geneva: Office of the United Nations High Commissioner for Human Rights, January 31.

UN Human Rights Committee. 2003. Gillot and Others v France (932/2000). A/57/40 at 270 (2002), 15 July 2002; 10 IHRR 22 (2003). Geneva: UN Human Rights Committee, paras. 13.2, 13.17.

UN Human Rights Committee. 2004. Guido Jacobs v Belgium (943/2000). CCPR/C/81/D/943/2000. Geneva: UN Human Rights Committee, para. 9.5, August 17.

UN Sub-Committee on Prevention of Torture. 2016. Approach of the Subcommittee on Prevention of Torture and Other Cruel, Inhuman or Degrading Treatment or Punishment Regarding the Rights of Persons Institutionalised and Treated Medically without Informed Consent. UN Doc. CAT/OP/27/2. Geneva: UN Sub-Committee on Prevention of Torture, January 26.

UN Working Group on Arbitrary Detention. 2015. Basic Principles and Guidelines on Remedies and Procedures on the Right of Anyone Deprived of His or Her Liberty by Arrest or Detention to Bring Proceedings Before Court. A/HRC/30/xx. Geneva: UN Working Group on Arbitrary Detention, June.

United Nations General Assembly. 1971. Declaration on the Rights of Mentally Retarded Persons, Resolution 2856 (XXVI). UN Doc. A/RES/26/2856. New York: United Nations General Assembly, December 20.

United Nations General Assembly. 1991. UN Principles for the Protection of Persons with Mental Illness. A/RES/46/119. New York: United Nations General Assembly. 
Venkatapuram, Sridhar. 2011. Health Justice-An Argument from the Capabilities Approach. Cambridge: Polity Press. Victoria Law Reform Commission. 2012. Guardianship: Final Report. Melbourne: Victorian Law Reform Commission.

(C) 2018 by the author. Licensee MDPI, Basel, Switzerland. This article is an open access article distributed under the terms and conditions of the Creative Commons Attribution (CC BY) license (http:/ / creativecommons.org/licenses/by/4.0/). 